\title{
Should Male Primary School Teachers be There Principally as Role Models for Boys?
}

\author{
Hannelore Faulstich-Wieland \\ Fachbereich Erziehungswissenschaft I, Fakultaetfuer Erziehungswissenschaft, Psychologie und Bewegungswissenschaft, University of \\ Hamburg, Hamburg, Germany \\ *Corresponding Author: Hannelore.Faulstich-Wieland@uni-hamburg.de
}

Copyright (C) 2013 Horizon Research Publishing All rights reserved.

\begin{abstract}
There is a worldwide debate about the need for male teachers as role-models especially for boys. This might motivate young men to start a teacher career expecting that their gender is the essential qualification. In a German project we interviewed upper secondary students regarding their study plans and found that most of them thought that teaching - i.e. in primary schools - would be both a rather boring job as to the intellectual demands and at the same time be rather challenging as to the personal dedication to children. Both make a teaching career unattractive for most of them. Future teachers in their first year of study, on the other hand, find the dedication to children exciting, but are not very interested in intellectual challenges. On such grounds, recruitment of men with role-model arguments - so the focus in this article - might result in a de-qualification of the teaching profession. The perspective must therefore emphasize the required competencies - including gender competencies.
\end{abstract}

Keywords Male role-model; students' study interests; gender competency

\section{Introduction}

The answer to the question posed in the title can be given beforehand by saying: No! They should be good teachers, and that means being responsible for all the children, and working professionally. This simple statement is, of course, not sufficient.

In the following I will therefore try to explain this answer argumentatively. At first I will demonstrate the notions schoolboys and schoolgirls have about what it means to be a teacher. Furthermore I will elaborate on the aspects of the teaching profession by which students are being attracted. In both sets of perceptions there is a clear distinction between the "pedagogical" and the subject-specific requirements of the profession. This distinction is problematic, and should be called into question by the educational study programs at university.
In a second step I will deal with the present demand to employ more male teachers especially in the primary school sector. The reasons given emphasize the role model effect that men have on boys, which is believed to improve boys' school performances and strengthen their gender identity. Empirical studies - which I will refer to briefly - could not substantiate an impact on boys' school performance. The reference to a gender-related role model effect however presents considerable difficulties which need to be clarified.

In a conclusion, the relationship between study motivation and the demonstrated difficulties will be reconsidered and I will try to shed light on alternative perspectives for good primary schools.

\section{Study Motivation of Secondary School Students and University Students of Education}

The research project "Männer und Grundschule" (men and primary schools) has been conducted at the University of Hamburg from 2008 to 2012. Within its framework, students of the upper secondary level ("Oberstufe") in eight high schools (Gymnasien) were questioned in group discussions about their future academic plans and their opinions about a career as a teacher. 95 young women and 86 young men participated in these discussions. All statements were transcribed and coded with relevant categories (e.g. preferred major at university, arguments for this major, arguments for or against teacher professions). Furthermore first-semester students who studied for a teaching credential were asked with an open questionnaire to give their answers regarding study motivation and opinions about their future profession in writing. 415 female and 139 male students filled out a questionnaire during first-semester classes. The open questions were coded into different arguments and proofed in SPSS for descriptive statistics (mean differences between groups). As a third method that is relevant for this article we took narrative interviews with six male teachers in primary schools and treated them the same way the group discussions were analyzed. 
A degree in teaching was rated very low by the students of the upper secondary level - only a small number of students considered this career a possible prospect for their future. The main reason given for this rejection was fear of personal stagnation in the job: a teacher has to teach the same material over and over again and reproduce confirmed knowledge only, instead of creating something new and rising to personal challenges. Particularly with regard to primary schools the students are of the opinion that teachers do not have to acquire or apply much subject-specific knowledge, but need only have perfunctory knowledge of all aspects of the subject and apply common sense in, for example, introducing basic arithmetic operations or conveying fundamental social values. The profession is mostly described as simplistic and monotonous. One student summarized this with the term "standstill".

A second line of argument refers to the increased public expectations with regard to teaching personnel: teachers are supposed to compensate for insufficient parental education while simultaneously being subject to parental pressure to support the children individually and to prepare them for a successful future. The respondents consider teachers to be "stopgaps" for the failure of society at large; they are perceived to be at the center of public criticism. Several students combine this line of argument with a tendency to exaggerate the challenges of the profession as exceedingly difficult and therefore meritorious. Particularly with regard to teaching in primary school they emphasize the great responsibility which comes with putting children on the "right track".

The male and the female students paint a picture of a teacher's everyday work life that combines two lines of thought, both rejecting the profession. Referring to the subject-specific content specifically, teaching at primary school is considered boring and undemanding, to the point of being very unchallenging, and students see hardly any room for (personal) development or career opportunities. At the pedagogical level, however - i.e. bringing up children and building a relationship with them (and their parents, respectively) - the teaching profession is seen as extraordinarily difficult and excessively demanding. This double strategy of rejection - which is what we called this line of reasoning - is interesting, because of the clear line that is being drawn between the perception of subject-specific content and the pedagogical side of the profession. Thus, the professional image of teachers appears ambivalent and doubly unsatisfactory.

In contrast to the small number of students in the upper secondary level, who are potentially interested in the teaching profession, there are a great many students who choose to study for a teacher's degree. In the winter semester of 2008/09 we launched a questionnaire survey of these first-semester students, including two open questions concerning their study motivation: What tipped the balance in favor of the teaching profession for them? What is the attraction in becoming a teacher? We summarized the answers in the analysis, because they recurred and were not specific for the respective questions. Five reasons were given by more than $20 \%$ of the women and men respectively (cf. figure 1):

-the desire to work with children/adolescents (e.g. "I love children")

-transferring knowledge (e.g. "I have fun passing on knowledge and teaching things")

-the opportunity to fulfill my interests and inclinations/subject combination (e.g. "strong interest in my subjects")

-positive experience of dealing with children/adolescents (e.g. "While I was still in the upper secondary level I did an internship at a primary school, which I really enjoyed.")

-the desire to bring up children (e.g. "The thought of being able to make a difference at school, to set an example and pass on my own values.")

There is almost no difference between the sexes in the order in which the statements were given. The frequency of the responses is also very similar. The desire to work with children and adolescents, however, is named noticeably more frequently by women than by men $(61 \%$ as opposed to $51 \%, \mathrm{p}<.05)$. The transfer of knowledge is also more often in the forefront of women's thinking - though not significantly - with $49 \%$ as opposed to $45 \%$.

More than $10 \%$ of the men's answers focus on job security, regular and sufficient leisure time and a good salary (each statement more frequently mentioned by men, $\mathrm{p}<.05$ ). Reconciling work and family life - although in total only mentioned by less than $10 \%$-is significantly more important to women than to men $(10 \%$ to $1 \%, \mathrm{p}<.01)$. It is also the women who believe more often that being a teacher is a creative job $(8 \%$ to $3 \%, p<.05)$ and who claim to have clear ideas of their future profession. For them it also seems to be more important to have an example set by a family member or a friend $(6 \%$ to $1 \%, \mathrm{p}<.05)$. Furthermore, it is remarkable that $4 \%$ of both sexes describe the teacher's degree as only their second choice, because they were not able to find a job or obtain a place at university in their chosen professional field (cf. figure 2).

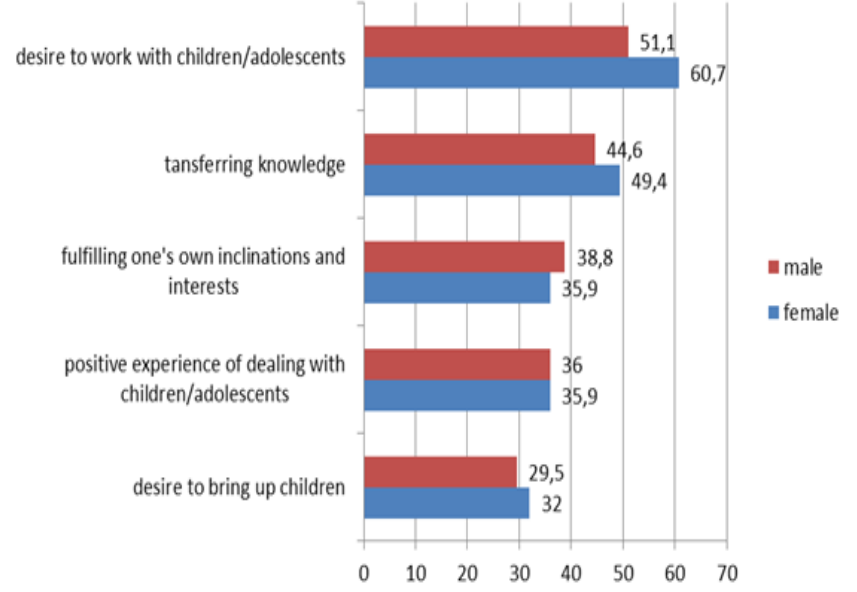

Figure 1. What is the appeal of their future teaching profession for the students? What tipped the scale in favour of a degree in education? Statements occurring in more than $20 \%$ of the responses 


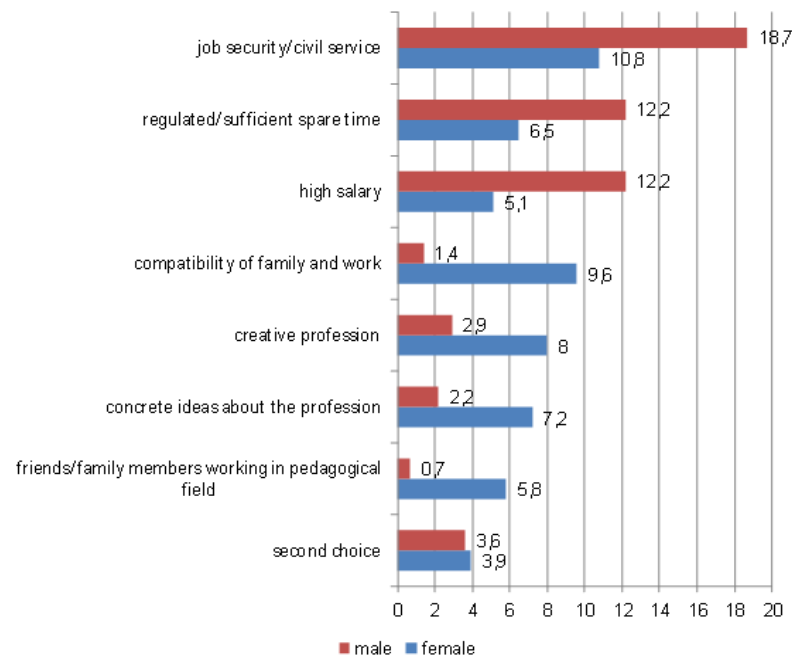

Figure 2. What is the appeal of their future teaching profession for the students? What tipped the scales in favour of a degree in education? Further differences between the sexes

The data provided by the students who have already decided that they want to work in the primary school sector was analyzed separately. The analysis shows that these students consider positive experience in working with children and adolescents to be particularly important. This corresponds to the fact that a large number of these students made their decisions in favour of the teaching profession only after completing their civilian service or an internship, which strengthened a desire that had already developed in the upper secondary level.

As expected, the defensive attitude of the students against working with children and adolescents is not shared by the future teachers. On the contrary, the students derive affirmation and joy from this work and choose their degree precisely for that reason.

What about the other defensive strategy? What about the presumption that teaching is not a sophisticated field of work? "Transfer of knowledge" might serve as the term for the scientific side of teaching - it refers to both the professional knowledge of subject-related content and professional knowledge of didactics (general and specialized didactics). Less than half of the female future teachers and only $45 \%$ of the male future teachers see this "transfer of knowledge" as the main appeal of their chosen profession. Just 30\% listed the opportunity to suit their own interests and inclinations. This corresponds with the results of a representative survey of students that HIS (=Hochschul-Informationssystem - a German Research Institute for Higher Education) conducted in 2007/2008. "Academic interest as the main motive for choosing one's degree is mentioned by only $24 \%$ of the students of the teaching profession, less frequently than by students of any other field" [1: 145 - translated into English].

The upper secondary students, in group discussion, assumed that especially work at primary schools made few intellectual demands. This is why we examined potential differences of opinion between future teachers of primary schools (up until lower secondary level, "Sek I") and upper secondary schools. We also considered possible differences between the sexes. We took into account those statements that referred to a desire to work with children and adolescents and also took into consideration possible indicators of "academic curiosity", that is, "transfer of knowledge" and "opportunity to pursue one's interests and inclinations" (cf. table 1).

Table 1. Differences in opinions between future teachers

\begin{tabular}{|c|c|c|}
\hline & female & male \\
\hline \multicolumn{3}{|c|}{ primary level including lower secondary $(\mathrm{f}=219, \mathrm{~m}=48)$} \\
\hline $\begin{array}{l}\text { desire to work with } \\
\text { children/adolescents }\end{array}$ & $69 \%$ & $60 \%$ \\
\hline transfer of knowledge & $44 \%$ & $50 \%$ \\
\hline $\begin{array}{l}\text { opportunity to fulfill one's own } \\
\text { interests and inclinations }\end{array}$ & $27 \%$ & $25 \%$ \\
\hline \multicolumn{3}{|c|}{ primary level only $(\mathrm{f}=135, \mathrm{~m}=25)$} \\
\hline $\begin{array}{l}\text { desire to work with } \\
\text { children/adolescents }\end{array}$ & $71 \%$ & $68 \%$ \\
\hline transfer of knowledge & $41 \%$ & $44 \%$ \\
\hline $\begin{array}{l}\text { opportunity to fulfill one's own } \\
\text { interests and inclinations }\end{array}$ & $30 \%$ & $16 \%$ \\
\hline \multicolumn{3}{|c|}{ Upper secondary level $(\mathrm{f}=118, \mathrm{~m}=71)$} \\
\hline $\begin{array}{l}\text { desire to work with } \\
\text { children/adolescents }\end{array}$ & $48 \%$ & $48 \%$ \\
\hline transfer of knowledge & $64 \%$ & $48 \%$ \\
\hline $\begin{array}{l}\text { opportunity to fulfill one's own } \\
\text { interests and inclinations }\end{array}$ & $48 \%$ & $44 \%$ \\
\hline
\end{tabular}

There are in fact considerable differences between students of the primary sector and those who study to become teachers at upper secondary schools (total values of primary school sector and upper secondary school sector show a difference that is highly significant): the desire to work with children and adolescents is mentioned noticeably less frequently especially by the latter - that is to say by only half of them. However, more than two thirds of the future teachers at primary/lower secondary level expressed that desire, with future lower secondary teachers taken by themselves showing a slightly lower figure. "Intellectual curiosity" is found more often among future upper secondary school teachers - notably with female students.

On the whole, these results concur with the data collected by HIS, who point out that,

"in accordance with expectations, first-year students of the teaching profession often state a desire to have a lot of social intercourse (87\%). The desire to have a lot of spare time is stated considerably more often by education students (41\%) than by fellow students of other subject groups. Ambitions to enter career-oriented, success-oriented and performance-oriented professions are clearly below average. Alarmingly below average is the proportion of first-year students of the teaching profession who want to gain professional recognition ( $44 \%$ vs. $67 \%$ in total) or who want to achieve an above-average performance in their profession 
(44\% vs. $60 \%$ ) - these proportions are the lowest of all first-year students" [1:312 - translated into English].

As expected, the upper secondary students' double strategy of rejection is not found among the university students. Working with children and adolescents is appealing and motivating for them. Nevertheless, an intellectual challenge is not essential for them - transferring knowledge is not seen as paramount, and contributing one's own interests and strengths is only partly of importance. Although there are differences between students of different school sectors, intellectual curiosity is not the leading motivation of prospective teachers as a whole, being even less central for the future primary school teachers.

We found that these prospective teachers are undemanding with regard to content-related expectations, that is, the scientific nature of educational studies and the intellectual level of the subject-specific knowledge that teachers need to transfer to their students. In contrast, the pedagogical side, that is, the educational work itself, relationships, and the contact with children and adolescents, represents the central attraction of their studies and the subsequent professional life to them. This view is expressed in statements like "accompanying and supporting children", "giving children something for life/conveying values", and the like. For us, however, the crucial point is that the students' perception and description of their future professional field is one of disconnection from the academic rigour of content. This means that subject-specific didactics are perceived as only of secondary importance, or at very least of lower priority than the pedagogical work that focuses on aspects of relationships and does not touch upon the didactic core of the profession. For these students, "pedagogy" seems to be primarily a question of attitude, and appears unrelated to the acquisition of knowledge or even to scientific rationality.

\section{Demand for More Men at Primary School}

We can now address the second line of reasoning: that the problems that many boys are experiencing at school - an argument prominent in the media but also heard from experts and politicians - calls for more men at primary school, in order for the boys to have male role models [for the international debate cf. $2,3,4,5,6,7,8,9,10]$. In the following I will follow up three main lines of argument and discuss their scientific validity.

\subsection{Improvement of Performance Through Male Teachers}

First of all, performance issues play an important part. The Minister of Social Welfare, Kristina Schroeder, ascribes the boys' lower performances seamlessly to the low proportion of male employees in kindergartens and in the primary school sector. She maintains that " $(T)$ he reason for the boys' worse performance is the fact that kindergartens and schools are female-dominated" (Interview in Die ZEIT on 4/22/2010 - translated into English).

If the high proportion of female teachers resulted in worse performance by boys, then boys would show better performance from being taught by male teachers. This assertion does not stand up to empirical scrutiny, as I will briefly demonstrate based on two recent studies [for an outline cf. 12]. These two studies proof the assumptions in German schools, but their results can be found in international studies as well [cf. 12, 13, 14, 15, 16, 17].

Martin Neugebauer et al. have analyzed the data from the German national supplementary study (IGLU-E) of the Progress in International Reading Literacy Study (PIRLS) 2001, focusing on the relevance of the teacher's gender for the competences and grades of the children 1 .

Overall - and after examining other potential influencing variables - the authors conclude that there is neither an advantage for boys having been taught by a male teacher nor for girls having been taught by a female [18: 14). On the contrary, regarding reading literacy it may even be disadvantageous for some of the children to have had a male teacher for four years (ibid.).

One of the authors of this study, Marcel Helbig, used the data of the Berlin ELEMENT-study (a longitudinal survey of primary school students in Berlin from their fourth to sixth grade in the years from 2003 to 2005), including reference to the teachers' gender, to test the three hypotheses listed below:

1.The development of cognitive competences in reading and mathematics becomes worse the more female teachers are at the school.This hypothesis cannot be confirmed. The reading competences of girls, however, increase with an increasing proportion of female teachers. Helbig supposes that this triggers the development of the girls' potential, but does not demotivate the boys [19: 103].

2. Despite equal cognitive performances, boys are awarded poorer grades by female teachers.This hypothesis was examined in subjects German and Mathematics. For German, it cannot be validated; for Mathematics, there is a weak correlation. On the whole, however, it turns out that boys cannot translate their competences as effectively as girls into corresponding grades. It can be presumed that this is more due to their attitude towards work than to the feminization of the school sector.

3. Boys less often receive a recommendation for grammar school than girls when there are more female teachers at the school. This correlation exists, but it is explained by the fact that grades are crucial for the recommendation. Thus, the third hypothesis should be rejected. Altogether, Helbig calls for further research efforts in order to scrutinize the connections. However, he rejects calls for more men at school on the grounds that this would improve boys' performance as untenable.Grading and particularly the way of addressing boys' behaviour are essential aspects in the

1The sample contained 2434 boys and 2389 girls being taught by a female teacher, and 553 boys and 482 girls being taught by a male teacher 
debate on the necessity of male role models.

\subsection{Can Female Teachers Deal with Boys Adequately or Can't They?}

One of the main criticisms is related to the alleged inability or reluctance of female teachers to adequately address the behavior of boys. "A diffident-feminine climate is dominant in kindergartens and schools", that is what the late educator Wolfgang Bergmann claimed in an interview with the Spiegel titled: "Boys have had enough of warm fuzzy pedagogics" [20]. Klaus Hurrelmann says that "boys like making their mark socially and physically, their behavior can be loud and conspicuous at times, they are more aggressive. They must not always only be told that their behavior is wrong" [21]. Giving feedback like this, he thinks, is more typical for female teachers than for their male counterparts. The underlying assumption here is that a different kind of pedagogical conduct is necessary - one which is practiced by male teachers - and that male teachers are more likely to take into account the interests of the boys.

In his article in HandbuchPädagogik, Allan Guggenbuehl offers pedagogical advice against school as a "female biotope" - as this title of his article suggests. He claims that "individualized pedagogy" does not take into account the "psychology of the sexes", as he calls his collection of examples of "normal" boy-behavior [22: 163]. According to him, these boys study and show commitment because this is required by "group norms" and the "system". They address a topic if a teacher prompts them and if it is addressed collectively (ibid.). Teacher-centered teaching is particularly important for boys because teachers then act as the "leader of the pack" ("Oberbandenfuehrer" is the original German title; ibid: 164). This behavior is important because resistance and heroism are vitally necessary for boys, which also means that as "leaders" the teachers have to react forcibly to the boys' behavior, they have to discipline and punish them (ibid.: 166). Guggenbuehl here refers to the assumption that male teachers are better suited to enforcing discipline and order.

Apart from this characterization of male behavior - which I find problematic - it is by no means true that a "feminine" style of teaching is prevalent among female teachers and a "masculine" style among male teachers. Barbara Read has analyzed the interaction style of teachers [23]. She differentiates two styles, the "disciplinarian style" and the "liberal discourse". The "disciplinarian" style is characterized by a continuing affirmation of the teacher's absolute authority. This is achieved verbally or through ritualized pedagogical or management practice. In contrast, there is little activity on the part of the students. If the students do not comply with the rules, strict reprimands and sanctions ensue. With the liberal style, however, power is displayed as little as possible, the students have many opportunities for their own activities and the teachers treat them almost as adults, i.e. on equal terms (ibid.: 613). The first style is regarded as "masculine" and is typically promoted in connection with a demand for more male teachers at school in order to attain a "boy-appropriate" culture. Such an attitude is both necessary and, as the argument goes, is only practiced by men. In reality, however, the disciplinarian style is found significantly more often than the liberal style, both are exercised by female and by male teachers, and a number of teachers practice them interchangeably. That means there is neither a predominantly "diffident-feminine climate" nor a female biotope, nor can the interaction styles be differentiated based on the gender of the teachers.

In addition, Brian Sevier and Catherine Ashcraft refer to the problematic nature of contrasting "female" and "male" teaching styles. They conclude,"if feminine styles of teaching are seen as a problem, it is unlikely that schools/classrooms could ever equally value both male and female teachers" [24: 536].

In a standardized survey of female and male students of the $8^{\text {th }}$ grade in Berne, Andreas Hadjar and Judith Lupatsch have examined (i.a.) the impact of the teachers' support on the school success of the adolescents. They showed that an "authoritative" style was able to reduce school estrangement and thus increase scholastic success. This is to be understood as a combination of leading the students by clear standards on the one hand and a genuine interest in them and in supporting them individually on the other hand [25: 91]). The gender of the teacher was immaterial.

Such a teaching style fits in with a modern conception of didactics, but in my opinion it does not correspond at all to the notion of a teacher being the "leader of the pack", as envisioned by Guggenbuehl.

\subsection{What Is Meant by Male Role Models?}

The third line of argumentation focuses on the necessity for men as role models. It is rarely clearly spelled out what that is supposed to mean. In a New Zealand study Penni Cushman questioned 169 head teachers (i.a.) about whether they see a need for male role models and if so, what exactly the need is. Two thirds were male headmasters. Fundamentally there were three reasons given: firstly, male teachers are supposed to be necessary for children of single mothers - "They need a father figure as too many in today's society are fatherless", says a 52-year-old headmaster [26: 130]. Secondly, they are supposed to be better at teaching boys' sports - a 50-year-old headmistress says that "male teachers are necessary to promote boys' sports, rugby", (ibid: 131). Finally they should stand for "manhood qualities"; as a 50-year-old headmistress stated: "not every male is a man" (ibid.). [For other studies with similar results cf. 27, 28]

\subsubsection{Teachers as father figures}

The idea that children, and boys in particular, are in need of a father figure and that a primary teacher should meet this need is indeed quite common [cf. i.a. 29]. It corresponds with the perception of female primary teachers' work as "maternal".

A US paper addresses the questionable nature of such 
references to fatherliness. Paul Sargent [30] studied with the reality of male primary school teachers. He interviewed 54 male primary school teachers, ten female primary school principals, six female principals of kindergarten and eight male university professors working in California, Oregon or Washington. The interviewees confirm that the field of Early Childhood Education (ECE) is a highly gendered work area which is associated with motherly tasks. He writes, "The image of teaching and childcare as women's work is powerfully supported by the use of 'mother' and 'mothering' as metaphors for, respectively, the job positions and job functions within ECE" (ibid.: 253).

If male teachers are now required to fulfill a male role model representing "fatherliness", this will also entail inconsistencies, as fatherhood is strongly connected with the male breadwinner model and/or the "disciplinarian". "Because early childhood education is framed through the metaphor motherhood, men cannot fit this metaphor while simultaneously living up to the expectations of hegemonic masculinity and fatherhood" (ibid: 155).

Sargent interprets his results in the light of Cornell's systems of masculinities and assumes a case of subordinate masculinity. There is no way out of this contradiction while this connection of primary school teaching with motherliness remains in force. This contradiction means that male teachers are under suspicion - for example, of sexual abuse if they show "motherly" behavior and that they are judged critically if they do not comply with the standard of male hegemonic behavior. The characteristics of hegemonic masculinity do not fit in with the demands of the profession, and the realization of subordinate masculinity contradicts the usual notion of "manhood".

In addition to the problems connected with fulfilling the role model of teachers as fathers, there are those that arise from the notion of fatherliness in relation to professional requirements.

\subsubsection{Male teachers - responsible for boys' sports}

A popular argument revolves around the idea that men can give boys the opportunity to engage in athletic competition and to let off steam by scuffling, wrestling and playing football. This also played an important role for the male teachers we questioned in the context of our project "Männer und Grundschule" (men and primary school). One teacher reported that he was hired only after agreeing to teach sports: "So I had a job interview with the then headmistress Ms. B and she said, yes, this all sounds fine, I can very well imagine that you will fit in, and great, a man at primary school and all. You will teach sports in the third grade then. And then I had to explain to her that I am really not suitable for teaching sports. Most of my life I had a D or E in sports and I told her from the beginning that this is out of the question for me. She then said to me, that is unfortunate, then we do not need you here. And that is what you will hear at any other primary school. Men have to teach sports at primary schools." (Mr. C. - translated into English)

This quotation shows that being a man is obviously equated with interest in sports and the suitability for teaching sports - relevant competences are thus considered a natural property of their gender. Furthermore, it is not about just any type of sport, but about the teacher being a partner or a rival "whom they can pit themselves against in sports lessons. Who maybe also does other things than just, let's say, always, always waving a play chute and singing and dancing, but someone who really also allows other games, wrestling, scuffling, romping about, stuff like that" (Mr. C. - translated into English).

This statement also reflects unquestioned assumptions, namely that boys are invariably interested in competing with their teacher, in scuffling, and are never interested in singing and dancing. The teacher we interviewed has adjusted to the expectations and himself eventually internalized them, including the negative view of allegedly female sports like dancing or gymnastics. This is no isolated incident within our sample, and it confirms cases reported on in the relevant literature [cf. e.g. 31]. However, structuring sports this way impedes a normal development for those boys who do not identify with competing, scuffling and wrestling because they are being marginalized, if not downright stigmatized. At the same time, it does not do justice to the girls, as they are either expected to adjust to sports behavior that is labeled "masculine" - which makes it impossible for them to develop a distinct female identification with it - or to withdraw themselves. This is not to be understood as an argument against scuffling, wrestling or competing. There are certainly many children, boys as well as girls, who are enthusiastic about it. The problem is that such practices are being gendered as "masculine" while simultaneously structuring different forms of sport hierarchically. Professional practice - keeping an eye on all the children and introducing them to the wide range and variety of sporting activities available - is not compatible with the practices engendered by the male-role-model discourse.

\subsubsection{Male role models - are they "real men"?}

Throughout the arguments already mentioned, we repeatedly find the assertion that when we are talking about role models, it is not about just any male teachers, but about "the right kind of man" [32]. Thus, the proponents' idea of "masculinity" has to be fulfilled and a redefinition of the work at primary schools has to ensue. Case studies and interviews are suitable methods to find out what is meant by "masculinity". Australian, Canadian and English studies are already available [cf. 33, 34].2 On the one hand these studies show that male teachers are confronted with different requirements than female teachers. The case of the young Australian primary teacher Brian is particularly illustrative [35: 127 et seq.]. He is in his mid-twenties, new at a primary school where he is in charge of a $2^{\text {nd }}$ grade class. Brian loves

\footnotetext{
$2 \mathrm{Cf}$. compilation of German and international literature on the subject of "more men into (elementary)school": http://www.epb.uni-hamburg.de/erzwiss/faulstich-wieland/Maenner\%20 und $\% 20$ Grundschule.htm
} 
reading, he practices a liberal teaching style, he uses the children's works as classroom decoration and always has an open door for visitors. Male and female students are enthusiastic about him. Male and female colleagues also like Brian, he takes part in discussions about pedagogical issues, but does not talk about his private life or about football. Although everything seems fine Brain is being pressured. He is supposed to become a football coach and to coordinate the "Responsible Thinking Classroom", an area where many disruptive students get sent to for a "time-out". Parents, male and female co-workers and the school administration all assume that Brian has to want more than just to be a good teacher, i.e. to take on administrative functions and leadership positions. Since Brain does not aspire to that, he is instead considering giving up his profession. For Lingard et al. this is explained by a system of masculinities in which the hegemonic position is the only one that counts, and which requires men to have career ambitions and to show aggressive competitive behavior. When Ulf Preuss-Lausitz calls for male role models at schools "in order to make real modern masculinities tangible between the obsolete "old masculinity" and the superficially well-behaved good boy" [36: 71 - translated into English], I presume that his aim is also to upgrade the image of previously marginalized masculinity. Most often, however - in my view Bergmann and Hurrelmann are prime examples - the call refers to the currently dominant type of hegemonic masculinity. Connell used the term "transnational business masculinity" for it [37]. Based on the example of business executives, Diana Lengersdorf and Mona Motakef examined the characteristics of this kind of masculinity: Diminished loyalty to one's company, a decreased sense of responsibility for others, and the acceptance of confrontational and aggressive behavior [38: 89].

However, this system of masculinities is but one aspect of the problem. A different one relates to gender relations. In the debate about the alleged feminization of the educational system, being a male role model means differentiating oneself from femininity. Within the two-gender system, localizations always follow dichotomous lines - masculine cannot be feminine and vice versa - which means that certain characteristics and forms of conduct are claimed as masculine and, simultaneously, denied to girls and women. This hegemony does not only apply within masculinity but also towards femininity. In plain terms, this is a revival of the hierarchical gender relations that lead to homophobia, sexism and misogyny [cf. 39, 40].

\section{Being Male Role Models as Motivation for a Teaching Degree - ARisk of Deprofessionalization}

Finally, we will revisit the hypothesis that the motivations of future teachers to study education, coupled with the specific requirement for male students to be future role models for boys, runs the risk of deprofessionalizing the teaching profession. Belonging to one gender as a crucial competence is formulated most clearly by Wolfgang Bergmann. Regarding complaints about the feminization of the school he concludes:

"One should open schools and kindergartens and bring in men. Not at all trained educators, mostly they do not do the children any good, anyway. Instead craftsmen, sculptors, men with life experience and a strong biography, with authoritarian traits, too, by which one can orientate oneself. Boys need that" (interview with Wolfgang Bergmann 2010 [20] - translated into English).

The listed arguments for male teachers all focus on the putatively natural properties of the gender: fatherliness as compensation for children of single mothers, affinity for sports as an expression of manly scuffling and the aggressive assertion of strength, are taken for granted. Reflective faculties, theoretical knowledge and, in general, questions about the content of education and the forms of educational processes are immaterial within these lines of reasoning. If students begin their studies with the desire to work with children and adolescents - attributing the decisive factor to the relationship - and if, at the same time, they are not interested in knowledge and science, they can be susceptible to such gendered role-model expectations. It may seem to them that these expectations can be fulfilled effortlessly provided they are men. Such an attitude, however, is by no means compatible with the requirements of either a good school or good teachers. By glamourizing the teachers' gender and demanding men who epitomize masculinity, we remain trapped in a dichotomous gender construction. Therefore, reflecting on gender images remains a task for all students, but especially the men in this profession. Thus, there remains the need for gender theories to be considered a need for interest in theoretical discourses. Since female teachers, too, are involved in the construction of gender - a point not studied here, but certainly worth studying - the task equally applies to the female students, of course. The blanket call for men to provide role models is highly problematic, the call for a professional teaching staff that consists of women and men, however, should be given full support. [cf. more detailed in 41].

\section{REFERENCES}

[1] Heine, Christoph/Willich, Julia/Schneider, Heinrich/Sommer, Dieter (2008): Studienanfänger im Wintersemester 2007/08. Wege zum Studium, Studien- und Hochschulwahl, Situation bei Studienbeginn. HIS. Hannover.

[2] Mills, Martin; Martino, Wayne; Lingard, Bob (2007): Getting boys' education 'right': the Australian Government's Parliamentary Inquiry Report as an exemplary instance of recuperative masculinity politics. In: British Journal of Sociology of Education 28 (1). 5-21.

[3] Carrington, Bruce; McPhee, Alastair (2008): Boys' 'underachievement' and the feminization of teaching. In: 
Journal of Education for Teaching: International research and pedagogy 34 (2). 109-120.

[4] Drudy, Sheelagh (2008): Gender balance/ Gender bias: the teaching profession and the impact of feminisation. In: Gender and Education 20 (4). 309-323.

[5] Martino, Wayne John (2008): Male Teachers as Role Models: Addressing Issues of Masculinity, Pedagogy and the Re-Masculinization of Schooling. In: Curriculum Inquiry 38 (2). 189-223.

[6] Skelton, Christine; Francis, Becky (2009): Feminism and "the schooling scandal". London: Routledge.

[7] Johnson, Shaun Patrick (2010): Still so Few Male Teachers: Now What? In: Young Children 65 (3). 18-23.

[8] Riddell, Sheila; Tett, Lyn (2010): Gender Balance in Teaching Debate: Tensions between Gender Theory and Equality Policy. In: International Journal of Inclusive Education 14 (5). 463-477.

[9] Skelton, Christine (2012): Men teachers and the "feminised" primary school: a review of the literature. Educational Review. In: Educational Review 64 (1). 1-19.

[10] Knight, Bruce Allen; Moore, Teresa (2012): Supporting beginning male teachers as they transform to skilled professionals. In: Improving Schools 15 (1). S. 61-72.

[11] http://www.bmfsfj.de/BMFSFJ/aktuelles,did=134950.html accessed on $6 / 29 / 2013$

[12] Faulstich-Wieland, Hannelore (2011): Werden tatsächlich Männer gebraucht, um Bildungsungleichheiten (von Jungen) abzubauen? In: Andreas Hadjar (Ed.): Geschlechtsspezifische Bildungsungleichheiten.Wiesbaden: VS Verlag für Sozialwissenschaften: 393-415.

[13] Sokal, Laura; Katz, Herb; Adkins, Matthew; Grills, Tannis; Stewart, Crystal; Priddle, Greg et al. (2005): Factors Affecting Inner-city Boys' Reading: Are Male Teachers the Answer? In: Canadian Journal of Urban Research 14 (1). 107-130

[14] Driessen, Geert (2007): The Feminization of Primary Education: Effects of Teachers' Sex on Pupil Achievement, Attitudes and Behaviour. In: International Review of Education 53 (2). 183-203.

[15] Carrington, Bruce; Tymms, Peter; Merrel, Christine (2008): Role models, school improvement and the "gender gap" - do men bring out the best in boys and women the best in girls? In: British Educational Research Journal 34 (3). 315-327.

[16] Holmlund, Helena; Sund, Krister (2008): Is the gender gap in school performance affected by the sex of the teacher? In: Labour Economics 15 (1). 37-53.

[17] Sokal, Laura; Katz, Herb; Chaszewski, Les; Wojcik, Cecilia (2007): Good-bye, Mr. Chips: Male Teacher Shortages and Boys' Reading Achievement. In: Sex Roles 56 (9) 651-659.

[18] Neugebauer, Martin/Helbig, Marcel/Landmann, Andreas (2011): Unmasking the Myth of the Same-Sex Teacher Advantage. In: European Sociological Review 27 (5). 669-689.

[19] Helbig, Marcel (2010): Sind Lehrerinnen für den geringeren Schulerfolg von Jungen verantwortlich? In: KZfSS Kölner Zeitschrift für Soziologie und Sozialpsychologie 62 (1).
93-111.

[20] Bergmann, Wolfgang (2008): Wohlfühl-Kuschel-Pädagogik geht Jungs gewaltig auf die Nerven. Interview Spiegel on April 5,2008:

http://www.spiegel.de/schulspiegel/wissen/0,1518,545037,0 0.html.Access on June, 29.2013.

[21] Hurrelmann, Klaus (2010): Sie wollen alles sein, bloß kein weibischer Streber. Interview Spiegel on April 23.2010: http://www.spiegel.de/schulspiegel/wissen/0,1518,688659-2, 00.html . access on June, 29.2013.

[22] Guggenbühl, Allan (2008): Die Schule - ein weibliches Biotop? Psychologische Hintergründe der Schulprobleme von Jungen. In: Matzner, Michael/ Tischner, Wolfgang (Ed.): Handbuch Jungen-Pädagogik. Weinheim: Beltz. 150-167.

[23] Read, Barbara (2008): 'The world must stop when I'm talking': gender and power relations in primary teachers' classroom talk. In: British Journal of Sociology of Education 29 (6). 609-621.

[24] Sevier, Brian/Ashcraft, Catherine (2009): Be Careful What You Ask For: Exploring the Confusion around and Usefulness of the Male Teacher as Male Role Model Discourse. In: Men and Masculinities 11 (5). 533-557.

[25] Hadjar, Andreas/Lupatsch, Judith (2011): Geschlechterunterschiede im Schulerfolg: Spielt die Lehrperson eine Rolle? In: Zeitschrift für Soziologie der Erziehung und Sozialisation 31 (1). 79-94.

[26] Cushman, Penni (2008): So what exactly do you want? What principals mean when they say 'male role model'. In: Gender and Education 20 (2). 123-136.

[27] Jones, Deborah (2008): Constructing identities: perceptions and experiences of male primary headteachers. In: Early Child Development and Care 178 (7). 689-702.

[28] Chan, Anita K. W. (2011): Feminising and masculinising primary teaching: a critical examination of the interpretive frameworks of male primary school principals in Hong Kong. In: Gender and Education 23 (6), S. 745-759.

[29] Aigner, Josef Christian/Poscheschnik, Gerald (2010): Jungen und Männer im pädagogischen Diskurs: zwischen Selbstbehauptung, Empirie und Geschlechterkampf. In: Erziehung und Unterricht 2010. 160 (5-6). 427-434.

[30] Sargent, Paul (2005): The Gendering of Men in Early Childhood Education. In: Sex Roles: A Journal of Research 52 (3-4). 251-259.

[31] Martino, Wayne John (2008): Male Teachers as Role Models: Addressing Issues of Masculinity, Pedagogy and the Re-Masculinization of Schooling. In: Curriculum Inquiry 38 (2). 189-223

[32] Jones, Deborah (2003): The 'Right Kind of Man': the ambiguities of regendering the early years school environment - the case of England and Wales. In: Early Child Development and Care 173 (6). 565-575.

[33] Francis, Becky (2008): Teaching manfully? Exploring gendered subjectivities and power via analysis of men teachers' gender performance. In: Gender and Education 20 (2). 109-122.

[34] Haase, Malcolm (2008): 'I don't do the mothering role that lots of female teachers do': male teachers, gender, power and 
social organisation. In: British Journal of Sociology of Education 29 (6). 597-608.

[35] Lingard, Bob/Martino, Wayne/Mills, Martin (2009): Boys and schooling. Beyond structural reform. Basingstoke: Palgrave Macmillan.

[36] Preuss-Lausitz, Ulf (2006): Arme Kerle! In: Psychologie heute (11). 68-72.

[37] Connell, Robert William (Raewyn) (1999): Der gemachte Mann. Konstruktion und Krise von Männlichkeiten. Opladen: Leske + Budrich. Original: (1995): Masculinities. Berkeley: University Press.

[38] Lengersdorf, Diana/Motakef, Mona (2010): Das praktische Wissen des unternehmerischen Selbst: Zwischen körperlicher Fertigkeit und praktizierter Männlichkeit. In: Angelika Wetterer (Ed.): Körper Wissen Geschlecht. Zu
Geschlechterwissen und sozialer Praxis. Sulzbach (Taunus): Helmer U. 79-94.

[39] Francis, Becky/Skelton, Christine (2001): Men Teachers and the Construction of Heterosexual Masculinity in the Classroom. In: Sex Education: Sexuality, Society and Learning 1 (1). 9-21.

[40] Haase, Malcolm (2008): 'I don't do the mothering role that lots of female teachers do': male teachers, gender, power and social organisation. In: British Journal of Sociology of Education 29 (6). 597-608.

[41] Faulstich-Wieland, Hannelore/Niehaus, Ingo/Scholand, Barbara (2010): Lehramt Grundschule: "niedrigste Stufe dieses Lehrerberufs" versus "ich liebe Kinder". Oder: Was SchülerInnen vom Lehramt abhält und Studierende daran reizt. In: Erziehungswissenschaft 21 (41). 27-42 